\title{
ПРАВОВА РЕГЛАМЕНТАЦІЯ НЕВІДКЛАДНИХ ВИПАДКІВ ПРОНИКНЕННЯ ДО ЖИТЛА ЧИ ІНШОГО ВОЛОДІННЯ ОСОБИ В ХОДІ ДОСУДОВОГО РОЗСЛІДУВАННЯ
}

Калугін В. Ю.

\begin{abstract}
У науковій статті досліджено проблемні питання дотримання прав та свобод громадян, правової реґламентації проникнення до житла чи іншого володіння особи у процесі досудового розслідування.

Недоторканість житла визнана світовим співтовариством одним із найважливіших принципів демократичної держави. Положення цього міжна родного принципу впроваджені в законодавство України та закріплені в Конституції нашої держави, $\epsilon$ основними принципами кримінального процесуального права.
\end{abstract}

Визначено та запропоновано вирішення проблемних питань дотримання прав і свобод громадян, правового регулювання проникнення в житло чи інше майно особи під час досудового розслідування. Чинний Кримінальний процесуальний кодекс визначає, що ніхто не має права входити до житла чи іншого володіння особи з будь-якою метою, крім добровільної згоди особи, яка ними володіє, або на підставі рішення слідчого судді. Крім того, слідчий, прокурор мають право лише в невідкладних випадках, пов'язаних з урятуванням життя чи майна, або у процесі безпосереднього переслідуванням осіб, підозрюваних у вчиненні кримінального правопорушення, винести клопотання до слідчого судді щодо проникнення до житла чи іншого володіння особи.

Аналіз чинного кримінального прочесуального законодавства та практики його застосування пов'язаний із необхідністю проникнення в житло у випадках, які не терплять зволікань. Запропоновано алгоритм дій працівників правоохоронних органів, які безпосередньо переслідують особу, яка підозрюється у вчиненні кримінального правопорушення і яка намагається сховатися в будинку чи іншому володінні особи, проведення дій, пов'язаних з особистим обшуком затриманого й огляду приміщення.

Обґрунтовано необхідність слідчого або прокурора ухвалити мотивоване процесуальне рішення в разі невідкладних випадків проникнення в житло й інше володіння особи як під час обшуку, так і в інших випадках, за винятком затримання особи під час безпосереднього переслідування.

Внесено пропозиції щодо вдосконалення деяких положень кримінального процесуального законодавства з метою дотримання прав і свобод під час проведення слідчих (розшукових) дій.
Ключові слова: досудове розслідування, недоторканність житла, правові підстави для проведення обшуку.

Kalugin V. Yu. Legal regulation of urgent cases of intrusion into the home or other property of a person during the pre-trial investigation

The inviolability of housing is recognized by the world community as one of the most important principles of a democratic state. The provisions of this international principle are implemented in the legislation of Ukraine and enshrined in the Constitution of our state and are the fundamental principles of criminal procedure law.

Problematic issues of observance of the rights and freedoms of citizens, and legal regulation of penetration into housing or other property of a person during the pre-trial investigation have been studied. The current $C P C$ requires that no one has the right to enter the home or other property of a person for any purpose, except with the voluntary consent of the person who owns them, or on the basis of a decision of the investigating judge, and the investigator, prosecutor have the right to issue a decision. the investigating judge to enter the home or other property of a person only in urgent cases related to saving lives and property or directly prosecuting persons suspected of committing a crime.

An analysis of the current criminal procedure legislation and the practice of its application related to the need to break into housing in cases that do not tolerate delays. An algorithm of actions of law enforcement officials who directly prosecute a person suspected of committing a criminal offense, who tries to hide in a person's home or other property, and actions involving a personal search to inspect the premises is proposed.

The necessity of the investigator or prosecutor to make a motivated procedural decision in case of urgent cases of intrusion into a person's home and other property, both during a search and in other cases, except for the detention of a person during direct prosecution, is substantiated.

Proposals to improve certain provisions of criminal procedure legislation in order to respect the rights and freedoms in conducting investigative (search) actions.

Key words: inviolability of dwelling, emergency cases of entering dwelling, search. 
Постановка проблеми та іï актуальність. У наукових працях, які присвячені розгляду різних аспектів слідчих (розшукових) дій, неодноразово було вказано, що під час їх проведення досить часто виникає потреба обмеження прав і свобод людини та громадянина. Цілком обґрунтовано, що нормативно визначені завдання кримінального провадження вказують на необхідність забезпечення розумного балансу приватних інтересів осіб і публічних інтересів у процесі кримінального провадження [1, с. 299].

Із цим варто погодитися. Саме досягнення розумного балансу приватних і публічних інтересів має стати орієнтиром для подальшого вдосконалення чинного кримінального процесуального законодавства, зокрема й щодо провадження невідкладних слідчих (розшукових) дій.

Недоторканність житла визнано світовою спільнотою як один із найважливіших принципів демократичної держави. Загальна декларація прав людини (ст. 12), ухвалена і проголошена Генеральною Асамблеєю ООН 10 грудня 1948 р., визначає, що «<...> ніхто не може зазнавати безпідставного втручання в його особисте і сімейне життя, безпідставного посягання на недоторканність його житла <...> Кожна людина має право на захист закону від такого втручання або таких посягань» [2].

Конвенція про захист прав людини і основоположних свобод (ст. 8) (Рим, 4.11.50) та Міжнародній пакт про громадянські і політичні права (ст. 17), ухвалений Генеральною Асамблеєю ООН 16 грудня 1966 р., передбачають: «Кожен має право на повагу до свого приватного і сімейного життя, до свого житла і кореспонденції. Органи державної влади не можуть втручатись у здійснення цього права, за винятком випадків, коли втручання відбувається згідно із законом для запобігання заворушенням чи злочинам, для захисту здоров'я чи моралі або для захисту прав і свобод інших осіб» $[3 ; 4]$.

Україна імплементувала зазначені принципи міжнародно-правових актів у національне законодавство. Однак недослідженими залишаються деякі проблеми, пов'язані з реалізацією засади недоторканності житла й іншого володіння особи під час провадження слідчих (розшукових) та процесуальних дій.

Аналіз останніх досліджень i публікацій. Питанням проникнення до житла й іншого володіння особи присвячені наукові дослідження таких вчених, як: Ю.П. Аленін, О.В. Білоус, І.В. Гловюк, Ю.М. Грошевий, С.В. Гончаренко, О.В. Капліна,
О.П. Кучинська, І.Ф. Літвінова, Л.М. Лобойко, В.Т. Маляренко, М.А. Погорецький та інші.

Метою статті $\epsilon$ визначення проблемних питань додержання прав i свобод людини, а також запропонувати алгоритм дій працівників правоохоронних органів у разі проникнення до житла чи іншого володіння особи у випадках, які не терплять зволікань.

Виклад основного матеріалу. У практичній діяльності правоохоронних органів непоодинокими $\epsilon$ випадки необґрунтованого обмеження права на недоторканність житла, порушення прав осіб під час провадження слідчих (розшукових) дій, неоднакового застосування норм ст. 233 Кримінального процесуального кодексу (далі - КПК) України, зокрема його здійснення до внесення відомостей до ЕРДР, оцінювання невідкладності випадків проникнення до житла й іншого володіння особи, юридичного значення згоди на проникнення його володільця тощо [4, с. 216].

Ст. 30 Конституції України передбачає, що не допускається проникнення до житла чи до іншого володіння особи, проведення в них огляду чи обшуку інакше як за вмотивованим рішенням суду.

Положення Конституції та чинного КПК України передбачають винятки із загального принципу недоторканності житла в невідкладних випадках, пов'язаних із врятуванням життя людей та майна, чи з безпосереднім переслідуванням осіб, які підозрюються у вчиненні злочину. Зокрема й $з$ необхідністю проведення в житлі огляду й обшуку.

Закон визначає, що обшук проводиться з метою виявлення та фіксації відомостей про обставини вчинення кримінального правопорушення, відшукання знаряддя кримінального правопорушення або майна, яке було здобуте внаслідок його вчинення, та для встановлення місцезнаходження розшукуваних осіб (ч. 1 ст. 234 КПК). Аналогічне й основне завдання проведення огляду (4. 1 ст. 237 КПК) [5].

Варто мати на увазі, що чинний КПК передбачає вимогу, що ніхто не має права проникнути до житла чи іншого володіння особи з будь-якою метою, інакше як за добровільною згодою особи, яка ними володіє, або на підставі ухвали слідчого судді, а слідчий, прокурор мають право до постановлення ухвали слідчого судді увійти до житла чи іншого володіння особи лише в невідкладних випадках, пов'язаних із врятуванням життя людей та майна чи з безпосереднім переслідуванням осіб, які підозрюються у вчиненні злочину (ст. 233 КПК). 
У результаті проведеного опитування слухачів курсів підвищення кваліфікації та перепідготовки Одеського державного університету внутрішніх справ (слідчі, співробітники оперативних підрозділів, дільничні офіцери національної поліції) було встановлено, що в разі виникнення невідкладних випадків, про які йшлося вище, чи необхідних випадків оглянути чи провести обшук житла й іншого володіння особи, уповноважені особи без будь-якого дозволу проникали до зазначених об'єктів та проводили слідчі (розшукові) дії. Протягом доби зверталися у визначеному Законом порядку до слідчого судді. Така процедура цілком відповідає чинному законодавству та міжнародно-правовим стандартам.

Передусім варто наголосити на тому, що можливість проведення обшуку в житлі чи іншому володінні особи у виняткових випадках практично не ставиться під сумнів.

Хоча щодо цього $є$ різні погляди. У засобах масової інформації наявна критика, що обшуки на підставі ч. 3 ст. 233 КПК проводяться через день, тиждень і навіть місяці після скоєння злочину. Тоді як «безпосереднє» переслідування можливе тільки відразу після того, як особа скоїла злочин, а особа, яка їі переслідує, натикається на перепони під час іï затримання через те, що підозрюваний переховується у відповідному житлі чи іншому володінні особи [6].

На жаль, законодавство не дає роз'яснення, які саме чинники впливають на визначення поняття «невідкладні випадки».

У результаті аналізу судово-слідчої практики можна виділити наступні слідчі ситуації, за яких можна провести обшук без отримання ухвали слідчого судді, а саме:

- невідкладність обшуку визначається обстановкою щойно вчиненого кримінального правопорушення;

- невідкладне проведення обшуку необхідне для припинення подальшої злочинної діяльності особи;

- у розпорядженні органів досудового розслідування $\epsilon$ достатні дані, які вказують на те, що особа, у якої знаходяться предмети і документи, які мають істотне значення для кримінального провадження, уживає заходів до їх знищення або приховування, у зв'язку із чим вони можуть бути втрачені;

- коли є реальна загроза, що особа, яка розшукується, перебуває в певному місці та може сховатися; коли фактичні підстави для проведення обшуку виникають під час провадження іншої слідчої (розшукової) дії;

- необхідність збору доказів, які $б$ підтверджували причетність особи до скоєння злочину, у разі затримання в порядку ст. ст. 207-208 КПК України.

Отже, як загальний критерій розуміння невідкладності випадку варто розуміти ситуацію, яка: виникла несподівано і випливає з динаміки розслідування чи суду; зумовлена дефіцитом часу для ухвалення рішення, коли немає можливості без шкоди для результативності слідчої (розшукової) дії звертатися до прокурора чи суду; несвоєчасне проведення обшуку призведе до втрати доказів.

На нашу думку, перед проведенням огляду чи обшуку в невідкладних випадках, за винятком випадків безпосереднього переслідування особи після вчиненого правопорушення, слідчий чи прокурор мають винести процесуальне рішення про проведення слідчої (розшукової) дії. Таке рішення по-перше, буде мати правову підставу для проведення таких дій, забезпечить виникнення певних процесуальних прав і обов'язків. По-друге, дана постанова буде додатковою гарантією дотримання процесуальних прав осіб, у житлі яких проводяться невідкладні слідчі (розшукові) дії, з можливістю її подальшого оскарження.

У бідь-якому разі судження про наявність у кримінальному провадженні «невідкладних випадків», покладене в основу даного процесуального рішення, має бути мотивованим і підкріплюватися конкретними матеріальними джерелами, які відповідають ознакам достатності.

Залежно від характеру слідчої (розшукової) дії, зокрема від того, наскільки вона пов'язана із вторгненням у сферу інтересів особи, ухвалення рішення про проведення слідчої (розшукової) дії, як слушно зазначає Ю.П. Аленін, «знаходить своє відображення в таких процесуальних формах: винесення спеціальної постанови, у якій містяться юридичні та фактичні підстави для проведення даної дії, наявність санкції прокурора або дозволу суду» [7, с. 176].

П.А. Лупінська до ознак кримінально-процесуальних рішення віднесла те, що вони породжують, змінюють чи припиняють кримінально-процесуальні відносини; мають бути винесені у встановленому законом порядку і виражені у визначеній законом формі [8, с. 24].

Ухвалення такого рішення слідчим чи прокурором буде висловлювати мотивацію, обґрунтування та позицію правоохоронних органів щодо необхідності проведення такої слідчої (розшуко- 
вої) дії. Причому можливе його проведення в нічний час, а в разі виникнення гостроконфліктної ситуації може проводитися за силової підтримки спецпідрозділів.

Європейський суд з прав людини та чинний КПК України зобов'язують працівників правоохоронних органів перед початком проведення огляду чи обшуку житла пред'являти ухвалу слідчого судді про дозвіл на проведення зазначених слідчих дій. Крім того, посадові особи ще до початку проведення обшуку чи огляду зобов'язані документально підтвердити свої повноваження і повідомити особу, що перебуває у приміщенні, про мету огляду чи обшуку, а також забезпечити присутність цієї особи чи їі близьких родичів, або інших представників під час проведення обшуку [9].

Уважаємо, що така вимога $є$ доречною в разі проведення слідчих (розшукових) дій у невідкладних випадках. У подальшому ця постанова буде підґрунтям мотивації клопотання до слідчого судді.

У науковій літературі розглянуто питання проведення огляду й обшуку житла за добровільної згоди особи, яка ними володіє. Можна підтримати Т.В. Лукашкіну, яка вважає, що поняття «проникнення до житла чи іншого володіння особи» $\epsilon$ загальним щодо будь-якого проникнення, з будь-якою метою [10, с. 116].

С.А. Шейфер слушно зауважив, що звернення слідчого до осіб, які проживають у жилому приміщенні та не бажають проведення в ньому огляду, розкриває наміри слідчого. Під час звернення слідчого до суду за рішенням на огляд між оголошенням про огляд і його фактичним проведенням створюється часовий інтервал, достатній для того, щоб особи, які заперечують проти огляду, змогли знищити докази. Фактично складається ситуація, коли огляд стає слідчою дією, яка має проводитися невідкладно, тобто без рішення суду» [11, с. 52].

Зовсім інша ситуація виникає в разі безпосереднього переслідування особи представниками правоохоронних органів, під час якого підозрюваний намагається сховатися в житлі чи іншому володінні.

Уповноважені службові особи, які здійснюють таке переслідування, можуть із метою його подальшого затримання в порядку ст. 207 КПК України проникнути до вказаного виду приміщень. Під час такого проникнення, яке здійснено уповноваженою службовою особою, виникає необхідність проведення огляду самого приміщення
3 метою виявлення предметів, які затримана особа могла викинути чи сховати у приміщенні.

Варто зазначити, що в невідкладних випадках затримання й обшук $є$ взаємозумовленими процесуальними діями. Адже коли відбувається затримання особи в житлі, де вона ховається від переслідування, то, очевидно, має бути проведений обшук із метою виявлення доказів учинення кримінального правопорушення.

Щодо затриманого проводиться особистий обшук, метою якого $\epsilon$ виявлення та вилучення предметів, речей тощо, що можуть бути небезпечними для оточення (вогнепальна, холодна зброя); якщо затриманий має намір звільнитися від предметів, документів, речей тощо, які вказують на його причетність до злочину (наркотичні засоби).

Особистий обшук може бути проведений без ухвали слідчого судді, а також без участі понятих, якщо він проводиться під час затримання особи в порядку ст. ст. 207, 208 КПК України, або поміщенні особи під варту, а також у разі наявності достатніх підстав уважати, що особа, яка перебуває у приміщенні або іншому місці, де проводиться обшук, приховує при собі знаряддя злочину, предмети, документи і цінності, які можуть мати значення для кримінального провадження.

У разі затримання осіб, підозрюваних у вчиненні злочинів, деякі складнощі викликає питання визначення правомірності затримання в порядку ст. 207 КПК України, оскільки затримання проводиться до внесення відомостей про кримінальну подію до ЄРДР.

Уважається, що в разі проведення фактичного затримання особи відомості про вчинення кримінального правопорушення негайно після його завершення повинні бути внесенні до ЄРДР, лише тоді повинен складатися протокол про затримання [13, с. 176].

Один із шляхів, який вироблений практикою. Щодо осіб, які затримані на місці вчинення злочину чи під час переслідування, спочатку складаються матеріали про затримання в порядку адміністративного провадження (ст. 261 Кодексу України про адміністративні правопорушення) [12], а після внесення відомостей до ЄРДР складається протокол у порядку, передбаченому ст. 208 кПК України.

Також є думка, що затримання особи може мати статус, аналогічний «огляду місця події», який у невідкладних випадках може проводитися й до відкриття кримінального провадження [14, с. 92].

Ще одне питання, яке досить часто виникає під час тлумачення положень ст. ст. 207 та 208 КПК, 
а особливо для випадків законного затримання, це розуміння поняття «уповноважена службова особа». Не вдаючись до детальної дискусії, можна підтримати бачення С.М. Смокова, який зазначає, що до уповноважених службових осіб можуть бути віднесені співробітники органів внутрішніх справ, співробітники, що здійснюють контроль за додержанням податкового законодавства, співробітники органів безпеки, співробітники органів Державної пенітенціарної служби, співробітники органів Державної митної служби, співробітники органів Державної прикордонної служби, а також слідчі та прокурори, якщо вони здійснюють затримання згідно з п. п. 1-2 ч. 1 ст. 208 КПК [5, с. 417].

Висновки. Отже, положення кримінального процесуального законодавства, які реґламентують порядок проникнення до житла чи іншого володіння особи в невідкладних випадках, потребують суттєвого вдосконалення. Невідкладний характер таких випадків зумовлює спрощення процедури під час обмеження конституційного права особи на недоторканність житла, що, у свою чергу, вимагає чіткості й ефективності їх законодавчого реґламентування.

\section{Література}

1. Гловюк І.В. Законне затримання та затримання уповноваженою службовою особою : питання теорії та практики. Наукові праці Національного університету «Одеська юридична академія». Одеса : Юрид. літ., 2014. Т. 14. С. 299-311.

2. Загальна декларація прав людини від 10 грудня 1948 р. Права людини. Міжнародні договори України, декларації, документи. Київ, 1992. С. 18-24.

3. Європейська конвенція з прав людини (Конвенція про захист прав і основних свобод людини від 4 листопада 1950 р.). Права людини і професійні стандарти для юристів в документах міжнародних організацій. Амстердам ; Київ, 1996. С. 12-17.

4. Міжнародний пакт про громадянські і політичні права (Міжнародний пакт ратифіковано Указом Президії Верховної Ради Української РСР № 2148-VIII (2148--08) від 19 жовтня 1973 р.).
5. Кримінальний процесуальний кодекс України. Науково-практичний коментар / за загал. ред. С.В. Ківалова та ін. Харків : Одіссей, 2018. 1099 с.

6. Атаманов О.М. Проникнення заради доказів. Закон і бізнес. 2019. № 38 (1440).

7. Аленін Ю.П. Шляхи вдосконалення початку досудового розслідування. Наукові праці Національного університету «Одеська юридична академія». 2013. T. 13. C. 175-184. URL: http://nbuv.gov.ua/ UJRN/Nponyua_2013_13_198.

8. Лупинская П.А. Решения в уголовном судопроизводстве : теория, законодательство, практика. Москва : Норма ; Инфра-М, 2010. 240 с.

9. Рішення Європейського суду з прав людини. Справа «Ратушна проти України», заява № 17318/06), Страсбург, 2 грудня 2010 р. URL: https: / zakon.rada. gov.ua/ laws/show/974_821.

10. Лукашкіна Т.В. Проникнення до житла чи іншого володіння особи: деякі питання. Сучасні проблеми реформування кримінальної юстиції в Україні : збірник матеріалів Інтернет-конференції, м. Київ, 28 листопада 2014 р. Київ : Національна академія прокуратури України, 2014. С. 116-117.

11. Шейфер С.А. Следственные действия. Основания процессуальный порядок и доказательственное значение. Москва : Юрлитинформ, 2004. 184 с.

12. Кодекс України про адміністративні правопорушення (ст. ст. 1-212-20. Відомості Верховної Ради Української Радянської Соціалістичної Республіки. 1984. Дод. до № 51. Ст. 1122. URL: https:// zakon.rada.gov.ua/laws/show/80731-10.

13. Макаренко Є.І. Правомірність затримання підозрюваного до відкриття кримінального провадження. Право і суспільство. 2013. № 4. С. 174-181.

14. Фаринник В.І. Затримання особи : проблеми кримінальної процесуальної регламентації та шляхи їх вирішення. Вісник кримінального судочинства. 2015. № 2. С. 85-94.

Калугін В. Ю., кандидат юридичних наук, доцент кафедри кримінального процесу Одеського державного університету внутрішніх справ 